\title{
VIRÁGH ÁGNES
}

viragha23@gmail.com

hallgató (DE BTK)

\section{A nápolyi hadjáratok ismeretlen epizódja: az aversai zsoldoslázadás ${ }^{1}$}

\section{The unknown episode of the Neapolitan campaigns: the mercenary revolt of Aversa}

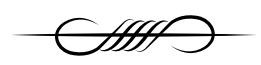

\begin{abstract}
Humanist authors regarded mercenaries with contempt, and in their works they gladly referred to those ancient writers who also condemned the utilization of mercenary armies. Mercenaries are mentioned in the Italian chronicles of the 14th century as well, and the author of the Cronaca senese recorded the brutal attack of John Hawkwood's company on Faenza. The notary of Apulia, Domenico da Gravina frequently reproved in his chronicle the German mercenaries on account of their excesses. In this paper I examine the passage that presents the mercenary revolt of Aversa, in which the Voivode of Transylvania, István Lackfi conducted a dialogue with the rebelling mercenary captains in order to reach an agreement with them.
\end{abstract}

\section{KEYWORDS}

mercenaries, Neapolitan campaigns, mercenary revolt, István Lackfi, Domenico da Gravina, Apulia

DOI 10.14232/belv.2020.2.6

https://doi.org/10.14232/belv.2020.2.6

Cikkre való hivatkozás / How to cite this article:

Virágh Ágnes (2020): A nápolyi hadjáratok ismeretlen epizódja: az aversai zsoldoslázadás. Belvedere Meridionale 32. évf. 2. sz. 119-132. pp

ISSN 1419-0222 (print)

ISSN 2064-5929 (online, pdf)

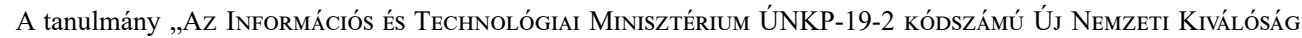
PROGRAMJÁNAK SZAKMAI TÁMOGATÁSÁVAL KÉSZÜLT." 
(Creative Commons) Nevezd meg! - Így add tovább! 4.0 (CC BY-SA 4.0)

(Creative Commons) Attribution-ShareAlike 4.0 International (CC BY-SA 4.0)

www.belvedere-meridionale.hu

Néhány évvel ezelőtt kezdtem el foglalkozni Domenico da Gravina (kb. 1300- kb. 1351) krónikájával (Chronicon de rebus in Apulia gestis ${ }^{2}$ ), a korábbi kutatásaim során a Chronicon magyarokkal kapcsolatos szöveghelyeit elemeztem 1347/1348-ra vonatkozólag, majd a vizsgálati periódust kibővítve, az 1348 ősze és 1349 tavasza közötti időszak magyar vonatkozásait vizsgáltam. Jelen tanulmány egy nagyobb munka része, amelyben a magyar hadi vezetőkkel kapcsolatos passzusokat gyüjtöm össze, s arra keresem a választ, milyen szerepük volt a hadi eseményekben. Minthogy a Chronicon kevésbé ismert, a tanulmány első részében röviden ismertetem annak tartalmát, illetve kitérek a főbb jellemzőire.

A krónikában szereplő események 1333-mal kezdődnek, ekkor került a Nápolyi Királyságba I. Károly magyar király másodszülött fia, András, aki szeptember 26-án feleségül vette I. Róbert nápolyi király örökösét, Johannát. A házassági egyezmény alapján András egyenrangú társuralkodó lett volna felesége mellett. Jelentős fordulópontja a cselekménynek 1343, amikor elhunyt Róbert, ugyanis András helyzetét a király halála elötti, január 16-án kelt végrendelet megváltoztatta, már csak házastársként szerepelt a szövegben, továbbá megkaphatta a Salernói Hercegséget. ${ }^{3}$ Mivel a nápolyi udvarban András királyi címét nem akarták elfogadni - noha a korona elnyerésére anyja, Erzsébet királyné és idősebb fivére, I. (Nagy) Lajos magyar király jelentős pénzösszeget fordítottak, továbbá több hatalommal is tárgyaltak,$- \mathrm{s}$ közvetlenül a megkoronázása előtt meggyilkolták Aversában (1345). ${ }^{4}$ Lajos és Erzsébet először VI. Kelemen pápától kérték, hogy büntesse meg a gyilkosságban vétkeseket, meggyőződésük szerint köztük volt Johanna is. Így az is a céljaik között szerepelt, hogy eltávolítsák a Királyság éléről, s az 1333-as szerződés értelmében Lajos jogot formált a trónra. A bünösök egy részének az elítélését jóváhagyta az egyházfö, ugyanakkor Johanna detronizálását nem fogadta el. Lajos két hadjáratot $(1347-1348,1350)$ vezetett személyesen a Királyságba, távollétében 1348 és 1350 között Lackfi István ${ }^{5}$ erdélyi vajda (1344-1350) állt a magyar sereg élén.

A hazai kutatás számára elsősorban a hadjáratok miatt értékes a krónika, újabban azt vizsgálták, miként jelentek meg a magyarok a külföldi szerzők müveiben. ${ }^{6}$ Az angolszász kutatók a Johanna királynőről készült életrajzok kapcsán idéztek részleteket András haláláról, vagy Tarantói

2 Legkorábbi példánya az Osztrák Nemzeti Könyvtárban található, jelzete: ms. 3465. CsukoviTs 2015. 207.; VIOLANTE 2016.; ND XI.; Kiadásaihoz lásd: ND XIV-XVI.

3 LÉONARD 1967. 397-399., 420-422.; TeISZler 2015. 63-79.; Kelly 2003. 281.

4 Casteen 2015. 35-50; Kelly 2011. 280-281.; LÉOnARD 1932. 465-473. Köszönet illeti Csákó Juditot, aki rendelkezésemre bocsátotta Léonard könyvét, ugyanis nehezen elérhető a hazai kutatás számára.

5 Korai pályaszakaszához lásd: FARKAS 2018. 13-34.

6 Pór 1892.; Miskolczy 1933a.; Miskolczy 1933b.; Miskolczy 1934.; Csukovits 2015. $205-213$. 
Lajos $^{7}$ hadvezéri alkalmatlanságát bizonyító szöveghelyeket használtak fel. ${ }^{8}$ Meglehetősen kevés azon olasz kutatók száma, akik behatóbban foglalkoztak a krónikával, az ő elemzéseik nagyrészt arra irányultak, hogy összehasonlítsák a szerző stílusát más kortárs itáliai kútfőkével. ${ }^{9}$

A krónikában a hadjáratok négy éve tekinthető a történet vázának, mellette a szerző kitért a Királyságban kialakult belpolitikai válságra, továbbá szülővárosának, Gravinának (ma Gravina di Puglia) a sorsát ismertette. Életéről igen keveset tudunk, csupán annyit, mint amennyit megoszt magáról a krónikában. Jegyzői tevékenységét homály fedi. Családjával elmenekült Gravinából 1349 tavaszán, miután a nápolyi-párt egyik hadvezére, Roberto Sanseverino ${ }^{10}$ bevette a várost. Ezután Bitontóban telepedett le, s itt fogott neki az írásnak. ${ }^{11}$ Nehéz lenne a Chronicont csupán egyetlen krónikatípusba sorolni, ${ }^{12}$ ráadásul jelentős különbségek mutatkoztak Itália északi és déli területeinek középkori történetírása között. ${ }^{13}$ Eric Willam Cochrane szerint az „Apuliai Krónika” tulajdonképpen a „nápolyi királyok krónikája”, hiszen Domenico narrációja

1347-től Johanna helyettese (vicario generale), akit 1347. aug. 22-én feleségül vett, bár VI. Kelemen pápától a diszpenzációt hét hónappal később kapták meg. 1348-ban felvette a Szicília és Jeruzsálem királya titulust, noha ehhez a pápai jóváhagyást csak 1350-ben szerezte meg. Végül Johannával együtt 1352-ben koronázták meg. KIESEWETTER 2006.

8 CASTEen 2015. 105.; BADDEley 1893.

9 Zabbia 1999. 121-143.; Delle Donne 1999. 301-314.; Az Anjou-kor historiográfiájához lásd: Morelli 2000. 1023-1045.

10 Sanseverino és Corigliano grófja, Terra d'Otranto ítélőmestere (giustiziere di Terra d'Otranto).

11 Caravale 1991.; Musto 2018. 18-19.

12 Előfordulnak benne autobiográfiai adatok, olykor csak egy városra fókuszál (Gravina), máskor az Anjou-dinasztia konfliktusára és a Nápolyi Királyságra (Regnum Siciliae). Csoportosításra lásd: FoOT - RoBINSON (eds.) 2012.; Deliyannis (ed.) 2003.; VAn CAEnEGEM 1979.; DALE - Lewin - Osheim (eds.) 2007.

13 Észak-Itáliában a 14. században nagyrészt olyan krónikák keletkeztek, amelyek középpontjában egy város állt. Szerzőik gyakran bankárok, kereskedők vagy jegyzők voltak, témáik között szerepelt a városlakók identitása és büszkesége. Jelentős antik müveltséggel rendelkeztek, inspirálódtak az antik auctorok munkáiból, s ezen munkák pozitív értékekkel bíró hőseit néha gonosztevőként mutatták be. Így cselekedett Gregorio (Goro) Dati (1362-1435) Istoria di Firenze címü művében, melyben Iulius Caesart mint zsarnokot prezentálta, ezzel az volt a célja, hogy érzékeltesse, a firenzeiek nemcsak az antik római virtus örökösei, hanem egyúttal a politikai szabadság és a republikánus berendezkedés védelmezői a zsarnokok ellenében. CochraNE 1981. 15.; VASINA 2003. 327-341.; Coleman 2007. 1-20. Mindazonáltal a városi típusú krónikáknál is lelhető példa a típusok keveredésére. Giovanni Villani (kb. 1280-1348) krónikájának (Nuova Cronica) első része olyan, mint bármilyen más világkrónika: a világ kezdetétől taglalta az emberiség történelmének jelesebb eseményeit, majd ezek ismertetése után tért ki saját városa, Firenze mitológiai eredetére és történetére. De még ekkor sem feltétlenül tisztán Firenzére irányult elbeszélése, hanem kora minden fontosabb történéséről említést tett. CLARKE 2007. 113-120. Kezdetben Dél-Itáliában a királyok regnálása került az elbeszélések középpontjába, hiszen annak területén előbb a normannok (1130-1194), a Hohenstaufen-dinasztia (1194-1266), majd az Anjou-dinasztia (1266-1442) szerezte meg az uralmat. Ugyanakkor a trecento során a déli történetírók már kevésbé tértek el az északiaktól, ugyanis hasonló műveltséggel rendelkeztek, valamilyen szinten ismerték a latin nyelvű irodalmat (latinantes). Müveikben helyet kaptak a déli városi kultúra értékei: a városlakók erényei és büntettei, illetve a narráció klasszikus hagyományokra épült, ehhez adaptálták a pogány és a korai keresztény történetírók terminológiáit. A déli szerzők az északiakkal párhuzamba állíthatók abból a szempontból, hogy ők is lényegesnek tartották a politikai és a kulturális intézmények eredetének és fejlődésének bemutatását, ugyancsak hangsúlyt fektettek a kollektív emlékezetre, különösen a vezető személyek erényei és bünei ismertetésekor. CoCHRANE 1981. 89-102., 119-133.; Abulafia 2005. 208-211.; Loud 2007. 29-49.; Musto 2018. xxiv-xxvii. A déliek müvei sem korlátozódtak tehát csupán a dinasztikus témára, a 14. század közepén alkotó nápolyi patrícius, Bartolomeo Caracciolo-Carafa (1300-1362) krónikája (Cronaca di Partenope) összetett struktúrájú: a világ kezdetétől saját koráig beszéli el az eseményeket, vagyis részben világkrónika, továbbá kifejeződik benne a Nápolyi Királyság népének közösségi identitása két vulgáris vers révén, amelyek a főváros népe kollektív emlékezetének lenyomatai. Kelly 2011. 3-4. 
a trónért harcoló uralkodókról szól, s minden ennek rendelődik alá, még Gravina birtoklása is, amelyért komoly harcot vívtak a két rivális hívei. ${ }^{14}$ Ronald G. Musto álláspontja az, hogy Domenico müve kevésbé tartható krónikának, hanem inkább müvészi gonddal megírt elbeszélés, amelynek keretét saját élményei, továbbá az egyéni és a közösségi emlékezet megnyilatkozásai adják. $^{15}$

Bizonyos szöveghelyeken harmadik személyü a narráció, ezekben az esetekben a szerző mások emlékezetére hagyatkozott, erre a szövegben is találhatók utalások ,, hír” (fama), ${ }^{16}$ „,közbeszéd” (publica fama), ${ }^{17}$ „, ugyanis nyilvánosan emlegetik” (fertur enim communiter), ${ }^{18}$,, szárnyra kelt a hír” (fama volante, infertur), ${ }^{19}$ illetve , ahogy hallottam, de nem láttam” (ut audivi, non vidi), ${ }^{20}$ „Hallottam ugyanis, hogy többen is azt beszélik...” (Audivi namque dici a pluribus...). ${ }^{21}$ Mindazonáltal szemtanúként volt jelen számos általa elmondott történetnél, a gravinai események ismertetésekor saját tapasztalataira támaszkodott, a magyarok táborában többször is megfordult, ott volt Lackfi István cornetói seregszemléjénél (1349. ápr.). ${ }^{22}$ A krónikás forrásait tekintve még nem tekinthető lezártnak a kutatás, az eddigi eredmények alapján annyi bizonyos: gyakran használt fel különböző bibliai történeteket annak érdekében, hogy még inkább érzékeltesse egy-egy esemény drámai jellegét. Szülővárosa egyik vezetőjének (Martuccio) kihallgatását Krisztuséval hasonlította össze, akinek megkínzása és bíróság elé állítása már-már a mártíromsággal is felérő megpróbáltatásként került bemutatásra. ${ }^{23}$ De korabeli tudományos példákat is használt, amikor a Durazzói-ház matriarchájának, Périgord Ágnesnek ${ }^{24}$ jó hírnevét egy orvos által végrehajtott vizeletvizsgálat részletes leírásával kívánta lerontani. ${ }^{25}$ Mindenesetre jegyzői munkája révén rendelkezett a közösség bizalmával (publica fides), ${ }^{26}$ több irathoz is hozzáfért, bár nagyon bonyolult módon viszonyult ezekhez, ugyanis szándékosan elhallgatta, pontosan milyen adatokra támaszkodott. Musto úgy vélte, ezt is a drámai hatás fokozása érdekében tette, és ezen információkat dialógusokba és beszédekbe építette be. ${ }^{27}$ Azonban a szerző néhány helyen utalt rá, hogy tudott egy-egy levél létezéséröl, noha a tartalmukról mindössze mások elmondásából szerzett tudomást. ${ }^{28}$

14 Cochrane 1981. 139.

15 Musto 2018. 55-56., 63., 66., 68.

16 ND 41.

17 ND 30.

18 ND 89.

19 ND 98.

20 ND 234.

21 Uo.

22 ND 191.

23 ND 230-233.; Delle Donne 1999. 312-313.; Musto 2018. 211-213.

24 Durazzói János felesége, fiaik: Durazzói Károly, Lajos és Róbert. Ágnes arra törekedett, hogy megszerezze a nápolyi koronát a Durazzói-ház számára, a krónikában Domenico hatalomvágyó intrikusként mutatta be, aki nagy befolyással bírt a nápolyi udvarban. LÉONARD 1932. 189-190.

25 ND 30-31.; Musto 2018. 249.

26 Delle Donne 1999. 303.; NusSDorfer 2009. 11-12.

27 Musto 2018. 97., 107.

28 Itt felmerül a hitelesség kérdése, tudniillik az, hogy a szerző számára kinek a szava bizonyult hitelt érdemlőnek. Az egyik ilyen szöveghelyen Nápolyból küldött leveleket említett, amelyeket Lackfinak küldtek. A krónikás ekkor éppen Barlettában tartózkodott a magyarok táborában, s a levelek tartalmát Lackfi közölte vele. ND 173. 
Az elöbb ismertetett példák azt mutatják, hogy érdemes több aspektusból is elemezni a krónikát, ugyanis azok nem merülnek ki a hadi cselekmények puszta leírásában. Csukovits Enikő mutatott rá, mennyire keveset tudunk az erdélyi vajdákról ebben a korszakban, s Lackfit illetően hiánypótló lehet a Chronicon. ${ }^{29}$ Jól használható adatok állnak rendelkezésre ahhoz, hogy megvizsgáljuk egy 14. századi apuliai jegyző véleményét a Nápolyi Királyságban 1333-1350 között történt eseményekröl. Jóllehet Domenico világa valóban kicsinek mondható egy világkrónika eseményeihez mérve, mégis információkban gazdag: magyar és idegen katonák jelentek meg a Királyságban, és a háború mellett vagy közben az új jövevények megváltoztatták a Királyság lakóinak életét.

A 13. századtól kezdve egyre több zsoldos harcolt Itáliában, ez a tendencia megfigyelhető a nápolyi hadjáratok esetében is. A krónikában az első információ erre vonatkozólag a capuai csatáról (1348. jan.) szóló helyen található: a magyarok oldalán németek és lombardok is küzdöttek, az ellenfél, Tarantói Lajos (1327-1362) seregében is akadt néhány német, provence-i és katalán zsoldos. ${ }^{30} \mathrm{~A}$ zsoldosok alkalmazását többnyire elítélték a szerzők, ${ }^{31}$ a legismertebb közülük Niccolò Machiavelli, aki szerint Itália - bár a 16. századi állapotokra vonatkoztatta, amikor a zsoldosok alkalmazása valóban széleskörüen elterjedtté vált - romlását a pénzért felfogadott katonák okozták, akiket a városok vezetői szerződtettek. Jellemzése alapján „Istent nem félik”, ${ }^{32}$ nem tartják meg ígéreteiket, fosztogatnak, azért harcolnak csupán, mert fizetséget kapnak. ${ }^{33}$ Machiavelli végül Polübiosz Történeti könyveinek azon részére hivatkozott, amelynél a történetíró az első pun háborút követően ismertette a karthágóiak és az általuk felfogadott zsoldosok szembenállását. Már nála is megfigyelhetők a zsoldosok ama tulajdonságai, amelyek alapján érthetővé válik egyes szerzők ellenszenve irántuk. ${ }^{34}$

Ez a minta a Chroniconban is felfedezhető, amikor Nagy Lajos 1348 tavaszán az Itáliában elterjedő pestis, illetve a velenceiekkel kiújult konfrontáció miatt visszatért Magyarországra, nem sokkal később Werner von Urslingen és kb. 1500 sisakosa a király zsoldját elhagyva

29 Csukovits 2016. 61-62.

30 Erant autem in exercitu dicti comitis pro parte regis Ungariae memorati Ungari, Theotonici et Lombardi et regnicolae hujus regni. Et cum domino Lodoyco Theotonici modici, Provinciales, Catalani modici et Neapolitani pro majori parte [...]. ND 82 .

31 A zsoldosok megvetését illetően Machiavelli a humanista tradíció folytatójaként értékelhető: Petrarca féktelenül szidalmazta a zsoldosokat, a Pierre de Poitiers-nek írott levelében többek között restségük és műveletlenségük miatt korholta őket. A firenzei Coluccio Salutati csavargóknak vélte őket, akik összeesküdtek a béke és a rend ellen, Leonardo Bruni a De militia címü értekezésében vette célba a zsoldosokat. MALlETt 2009. 207-209.; CAFERRo 2003. 288. Machiavelli müveit és azok kritikáját újabban revideálták: ERwIN 2010. 541-574. A Cronaca senese szerzője Domenicóhoz hasonlóan megörökítette a zsoldosok túlkapásait. Amikor 1371-ben John Hawkwood kompániája Faenza ellen vonult, kegyetlen vérontásba kezdtek. A kompánia tagjai közül Hawkwood volt a legkegyetlenebb, ugyanis amikor két kapitánya összeveszett egy fiatal lány megbecsetelenítése miatt (ti. melyikük legyen az első), Hawkwood eldöntötte a vitát: tőrét a lány szívébe szúrta. Cron. sen. 637.

32 Ezt akár szó szerint is lehet érteni, a Pistoiai Történet szerzője arról számolt be, miszerint a nápolyi hadjáratokban is részt vevő német condottiere, Werner von Urslingen mellvértjén nem állt más, mint ,ellensége Istennek, az irgalmasságnak és a könyörületnek” (nemico di Dio, di pietà e di misericordia). Stor. Pist. 182.

33 Mach. 62.

34 Pol. 60-61. 
átálltak a nápolyiakhoz. ${ }^{35}$ Jóllehet a szöveg ezen részéből nem derül ki, mi állhatott az árulás mögött. Egy másik kortárs kútfö, a firenzei Matteo Villani elbeszélése közelebb visz a megoldáshoz: mivel Wernerék nem kapták meg a fizetségüket, ${ }^{36} \mathrm{~s}$ ezt úgy tudták könnyen pótolni, ha új szolgálatot vállaltak. Ez alapján joggal merül fel a kérdés, hogy ekkor valóban sor került-e árulásra? Hiszen a zsoldosok azzal kötöttek szerződést, aki meg tudta fizetni őket, s nyilván egy háborúban hamar elfogyott az utánpótlásuk, amit vagy a lakosság sanyargatása és kifosztása révén pótoltak, vagy pedig új szerződést kötöttek. ${ }^{37}$ Domenico mégis úgy látta, hogy árulás történt, amikor Cornetóban a magyarok elfogták Wernert (1349. febr. 1.), akit kihallgatása során Lackfi szintén árulással vádolt meg. ${ }^{38}$

A fosztogatásról több példa is található a Chroniconban. Az erre vonatkozó szöveghelyeket kétféleképpen lehet csoportosítani. Az egyik esetben az utánpótlás beszerzése nem azonos a lakosság kifosztásával, ugyanis a krónikás természetesnek vélte azt, hogy a hadsereg ellátását egy elhúzódó háborúban biztosítani kell. Azonban ezen közléseket érdemes kritikusan szemlélni, mivel minden ilyen említésnél Lackfi István serege számára történt a hadtáp beszolgáltatása. ${ }^{39}$ Lackfit pedig csodálatra méltó hadi vezetőnek tartotta, s a szerzőben fel sem merült annak a lehetősége, hogy a lakosság számára a hadi készletek ilyen módon történő feltöltése ugyanolyan terhesnek tünhetett, mintha csak a zsoldosok követeléseit teljesítették volna. ${ }^{40} \mathrm{~A}$ másik esetben már egyértelmüen fosztogatásnak tekintette azt, amikor a zsoldosok követeltek ellátmányt a lakosságtól. Sőt, úgy tünik nem volt különbség a zsoldosok és a nápolyiak zsákmányszerzése között, mindkettőt egyaránt súlyos megpróbáltatásnak tartották Gravinában. Amikor Roberto Sanseverino serege bejutott a városba (1349. ápr.), a város népe kénytelen volt minden vagyonát a katonák rendelkezésére bocsátani „,zsoldosok és haramiák, óriási pusztítást végeztek a városlakók körében, s javaikat elvéve fosztogattak. A nép közül senki sem mert nyíltan beszélni, de titokban feljajdultak". ${ }^{41}$

35 „Lám, mindezen események közepette megérkezett ugyanoda a nápolyiak részéröl az említett palatinus [Giovanni Pipino], a német vezérrel, Guarnierivel [Werner von Urslingen] együtt, akik ezerötszáznál több sisakost hoztak magukkal; s beléptek Nápoly városába, hogy a királynö helyett harcolni ajánlkozzanak a magyarok ellenében." Ecce inter haec media pervenit ibidem a romanis partibus Pallatinus jam dictus, una cum duce Guarnerio theotonico, habentes secum barbutas Theotonicorum ultra mille quingentas; et ingressi civitatem Neapolis obtulerunt se pro eadem regina contra Ungaros pugnaturos. ND 105-106. Werner (†1353) 1342-ben alapítója volt az első Nagy Kompániának (Grande Compagnia), 1347-től Nagy Lajos szolgálatában állt, majd a nápolyiakéban, 1349-től ismét a magyarokéban. A barbuta kifejezést elsősorban a német zsoldosokra alkalmazták, másodsorban azokra a katonákra, akik az előbbiekhez hasonló felszereléssel rendelkeztek. Mallett 2009. 32.; VAGLIENTi 1999. 4-5. Giovanni Pipino Altamura grófja, kezdetben Nagy Lajost támogatta, majd Johanna mellé állt, akitől Molfetta és Giovinazzo városokat kapta. 500 zsoldosa volt, akik rettegésben tartották a két város lakóit. DALL'Oro 2008. 62., 86-87.

36 Villani 174.

37 DALl'Oro 2008. 70-71.

38 ND 139.

39 Mielőtt Lackfi 1349 tavaszán elért volna Cornetóba, alaposan kifosztotta a környező várakat (Canosa, Guadiano), Cornetóban ekkor szinte mindenből hiány volt. ,, Ugyanazon a napon a vajda visszavonult Canosától, amit mindenfelé kifosztottak és elpusztitottak, majd egyenes úton bevonulva Guadiano földjére hevesen küzdöttek, amilyen hirtelen lerohanták, ahhoz hasonlóan rombolták le, s végre megközelitették Cornetót." Eodemque die recesserat idem dominus Voyvoda de civitate Canusii quam undique praedaverant et consumpserant, et recto tramite incedentes ad terram Gandiani, acriter militaverunt, quam subito aggredientes, similiter destruxerunt, et demum applicuerunt Cornetum. ND 191.

40 Nagy Lajos és a zsoldosok kapcsolatának eltérő értelmezését lásd: ABULAFIa 2005. 215.

41 stypendyarii et malandreni sequentes dictorum exercitum dominorum magnam stragem faciebant in populum civitatis, tollendo bona eorum et disrobando. Nec quisquam populi ausus est loqui, sed in occulto clamabant. ND 220. 
Werner elpártolását kivéve 1349 öszéig Lackfinak nem akadt komolyabb gondja a zsoldosokkal, mindazonáltal Aversában ${ }^{42}$ szembekerült velük. Az aversai lázadás nem szerepel a hazai kútfők (Küküllei János, Névtelen szerző) müveiben, még abban az 1350-ben kiállított oklevélben sem említették, ${ }^{43}$ amelyben Lackfi azon érdemeit és tetteit sorolják fel, amelyek a nápolyi hadjáratokhoz kötődnek. Az egyetlen logikus magyarázata ennek az lehet, hogy ez a történet nem illeszthető be a győzelmek sorába, nemcsak Lackfit, hanem az uralkodót is kedvezőtlen színben tüntetné fel. Továbbá Matteo Villani ${ }^{44}$ szolgáltat rövid leírást a magyarok és a zsoldosok kapcsolatáról, mindenesetre a történet itt sem szerepel, erre a későbbiekben visszatérek.

Domenico a konfliktust párbeszédes formában ismertette. 1. Igen nagy jelentőségünek tarthatta ezt a konfrontációt, amelyet az is bizonyít, hogy nagyon aprólékosan kidolgozta a szöveg ezen részét. Ehhez hasonló, részletekbe menő szövegalkotás a krónikában szereplő események közül azoknál figyelhető meg, amelyek a krónikás felfogása szerint kiemelkedő jelentőséggel bírtak. ${ }^{45}$ Ide tartozik az ellenfelek kihallgatása (Werner, Giovanni Pipino), a csatákat megelőző tárgyalások, ugyancsak ide sorolhatók a Gravinával kapcsolatos közlések is, melyeknek részletes taglalása érthető okokból lényeges volt számára. 2. A lázadás idején a szerző éppen Bitontóban volt, ennek ellenére, ha közvetve is, úgy írhatta meg ezt a dialógus-sorozatot, hogy annak részleteit az incidensnél jelenlévők szóbeli beszámolója révén alaposan ismerte. Krónikájából tudjuk, miszerint több magyar hadi vezetővel személyes ismeretségben állt, ${ }^{46}$ ezért valószínü, hogy a történet a magyarok nézőpontját tükrözi. Az 1349-re vonatkozó eseményeket illetően a krónika írása szinte párhuzamosan követi a bemutatott történetek idejét, ${ }^{47}$ így annak a lehetősége csekély, hogy a lázadás szemtanúinak emlékezete megkopott volna a közben eltelt idő során.

A lázadás elbeszélését azzal kezdi, miszerint a „németeknek dölyfös népe” (superbum genus Theotonicorum) a kifizetetlen zsold miatt Terra di Lavoro ${ }^{48}$ tartományát felprédálta, amit Lackfi nagy küzdelem révén szerzett meg ,fegyverei erejével” (acquisiverat virtute armorum). ${ }^{49}$ Majd kitért rá, hogy a zsoldosok zsarnoki természetét ez sem elégítette ki, mivel erőszakosan

42 Nápolytól 32 km-re északra van, a fỏváros egyik stratégiailag fontos pontja, jelentős szerepe volt a főváros védelmében.

43 Aokl. XXXIV. 706. sz.

44 Giovanni művét testvére, Matteo (†1363) folytatta 1348-tól 1363-ig, majd utóbbi fia, Filippo 1364-ig. CLARKE 2007. 113., 124-127.

45 A kutatók közül többen is úgy látták, hogy ekkor a szerző stílust vált: jegyzői pontossággal adja elő a történetet, leírása kevésbé személyes, és törekszik a részletek bemutatására. Musto 2018. 85-86; Delle DonNe 1999. 311.

46 A magyarok barlettai táborából Csúz János és kb. 300 magyar és német lovas, továbbá kb. 100 gyalogos indult el, hogy felmentsék a nápolyiak támadása alól Gravinát és környékét, a szerző is velük tartott. Csúzt úgy említette, mint aki ,szakértője a hadmüveleteknek” (actibus bellicis eruditus). ND 160-161. Csúzt homo novusként jellemzi az újabb szakirodalom, mivel gyors előmenetele mögött jórészt a hadjáratokban megmutatkozó érdemei álltak. KARLINSZKY 2011. 28-29. A forrásokban kezdetben Chuz néven fordul elő, majd Ludbreg néven. 1357-1358 között még Csúz János néven horvát-dalmát bán, 1368-tól Ludbregi János (Johannes de Ludbreg) néven szerepel. WERTNER 1908. 134-135; ENGEL 1996. 23, 484. 1353-ban tért vissza Itáliából, egy 1353. okt. 12-én kelt oklevél szerint Miklós fia Gergely kifosztotta Csúz Itáliából visszatérő famulusait és servienseit. Borosy 2005. 63. Domenico 1348 öszén Manfredoniában volt, amikor Lackfi partra szállt 300 fös seregével: „ime a nemes férfiú, István, erdélyi vajda, háromszáznál több magyar nemessel megérkezett a tengeren keresztül a Királyságba, Manfredoniába” ecce generosus vir Stephanus Voyvada transilvanus ad regnum pervenit in Manfredoniam per mare, cum Ungaris nobilibus ultra trecentos. ND 133.

47 Delle Donne 1999. 304-305.

48 A főváros számára rendkívül fontos volt ez a tartomány, innen szerezték be az élelmet.

49 ND 318. 
követelték a nekik járó 150 ezernél is több aranyforintot, tudniillik ekkora összeggel tartozott nekik Nagy Lajos hónapok óta. ${ }^{50}$ A dialógus további sorai alapján megállapítható, a „dölyfös” jelzőre valóban rászolgáltak a németek, mert mindenáron hozzá akartak jutni a jussukhoz. Lackfi válaszában az erőszakos követelésre türelemmel reagált „Minthogy tudjátok, már rég követeket küldtem király urunkhoz Magyarországra, hogy jelentsék neki az ügyet és kérjenek pénzt, a korábbi és a jövendö zsoldotokra; kívánatos, hogy kitartsatok a követeink megérkezéséig" ${ }^{51}$ Lackfi hadi vezetőként jól tudta, mennyire fontos egy sereg számára, hogy megfelelő fizetségben részesüljön, ezért készségesnek mutatkozott a követelés teljesítésében. Ráadásul arra is figyelemmel kellett lennie, hogy a követelés elutasítása vagy indulatos válasz esetén el is veszítheti a zsoldosokat, akikre továbbra is nagy szüksége volt. A magyaroktól elpártolt zsoldosok az ellenfél szolgálatába szegődhettek volna - amint erre már korábban sor került -, ami igen hátrányosan érintette volna a magyarokat. Lackfi annak érdekében, hogy biztosítsa a zsoldosok kitartását és harci kedvét, a zsold duplán történő megfizetését ajánlotta fel.

A zsoldosok azonban minél hamarabb fizetséghez szerettek volna jutni, ezért azzal a tervvel álltak elö, hogy a három hónappal korábban elfogott nápolyi elökelők szabadon engedéséért cserébe váltságdíjat szednek ,gondoskodtunk róla, mivel híján vagytok a pénznek, hogy az ország elöbb említett nemeseit, akiket fogságban tartunk, pénzen váltsák meg, amelyet a mi zsoldunkra kell fordítani". ${ }^{52}$

A dialógus hangneme itt már mindkét félnél azonos, hiszen Lackfit mint hadi vezetőt és a király megbízottját, felháborította a zsoldosok terve „Íme, látom, hogy ti úgy beszéltek, mintha árulók lennétek". ${ }^{33}$ Válaszából az árulás szót érdemes kiemelni, nem kétséges, hogy ezt nemcsak az indulatot érzékeltetni akaró krónikás, hanem Lackfi is árulásnak tartotta, míg a zsoldosok szemszögéből nézve mindez csupán egy eszköz volt, amellyel rövid időn belül megoldhatták pénztelenségüket. A magyarok és a zsoldosok eltérően vélekedtek arról a csatáról ${ }^{54}$ is, amelynek eredményeképp nápolyi előkelőket tudtak foglyul ejteni. A magyarok álláspontját Lackfi révén ismertette a krónikás „Ugye nem tagadhatod, Corrado uram [Konrad Wolfurt], hogy aznap, miután a csata elkezdödött, fogságba estél az ütközetben kíséreted több tagjával együtt a vetélytársak ereje folytán, majd fogolyként Nápolyba vittek, és a ti részetekröl a csata elveszett, s a mi magyarjaink az ellenséget hátba támadván, csak összecsapás árán szerezhettek vissza téged és nyerhették meg az általatok elvesztett csatát?" ${ }^{55}$

50 Coeperunt autem Theotonici cum inportunitate petere dicto domino Voyvadae gagia eis debita pro tempore praeterito mensium junii, julii et augusti, quae erant in summa ultra centum quinquaginta milia florenorum. ND 319.

51 Scitis quia dyu expressos nuntios miserim ad dominum nostrum regem apud Ungariam, nuntiare sibi causam et pecuniam quaerere pro gagiis vestris praeteriti temporis et futuri; oportet vos sustinere usque ad nuntiorum adventum. Uo.

52 et providimus, quod ipsa caretis pecunia, praedictos regni magnates quos captivos habemus, pecunia liberari, nostris gagiis convertendam Uo.

53 Ecce video vos quasi proditorie loqui... ND 321.

54 Melitónál került rá sor 1349. jún. 6-án. Nápolytól és Aversától azonos távolságra található, a szembenálló felek számára ideális terepnek bizonyult. A szakirodalomban nápolyi csataként is előfordul, azonban tévesen, bár a fővárosig üldözték a magyarok és szövetségeseik a nápolyiakat, ám a városba nem jutottak be.

55 Nonne diffiteri posses tu, domine Corrade, quod die commissi proelii non fuisses captus in proelio cum pluribus tuae sequelae potentia aemulorum et captivus Neapolim ferebaris et vestra parte proelium erat ammissum, nisi Ungari nostri, inimicorum ferientes a tergo, te recuperassent in pugna et ammissum per vos proelium revicissent? ND 321322. Konrad Wolfurt német zsoldosvezér, testvére Ulrich, mindketten Nagy Lajos szolgálatában álltak. A krónikában Lackfi egyik tanácsadójaként szerepel, a vajda mellett harcolt 1348 őszétől a lázadásig. DALL'Oro 2008. 88. Ulrich (1350-1352) mosoni, soproni és vasi ispán, illetve óvári várnagy volt. Konrad (1357-1359) soproni ispán volt. 1390től Vöröskői néven szerepelnek. ENGEL 1996. 155-156. 
A szerző szerint Lackfi ezután is képes volt elörelátóan és bölcsen gondolkodni, ugyanis a zsoldosok emlékeztették arra, hogy a túszokat közösen fogták el, így már ő sem látta annak akadályát, hogy váltságdíjat követeljenek értük. Jóllehet, korábban azt ajánlotta, küldjék öket Magyarországra, s akkor a király is arra fog törekedni, hogy pótolja az elmaradását. Ugyanakkor hiába küldött követeket a zsold kifizetése ügyében Lajoshoz, az összeg egy részét mihamarabb az elégedetlen zsoldosok rendelkezésére kellett bocsátani. Lackfi elgondolása alapján 100 ezer aranyforintot remélhetnek a foglyok szabadulásából, a maradék összeg kifizetéséig pedig saját fiát, Miklóst ajánlotta fel túszul „A fennmaradó összegért cserébe nektek adnám túsznak Miklós fiamat, hogy magatokkal vigyétek németföldre, amíg a királyi felség kifizet benneteket. ${ }^{56}$

A dialógus további részében Werner is feltünik, akit a szerző „nagyszerü és nagyon okos ember" jelzőkkel illetett, akiről nyilván továbbra sem volt jó véleménnyel, mivel igencsak ellenszenvesnek tünnek a szavai „Javaslom tehát, hogy vegyük újra elö az elfogott urakat, s préseljünk ki belölük vesszözéssel egy csinos kis váltságdijat". ${ }^{57}$ Werner erőszakossága nem meglepő mellvértje szövegének ismeretében, s ebben a krónikás szerint a többi zsoldos is örömét lelte „,már mennek is a németek nagy kedvvel, hogy a foglyokat elövezessék a kínzásra”. ${ }^{8}$ Domenico az ismertetés előtt megjegyezte: a kínzások módjáról Lackfi titkárától, egy Miklós nevü jegyzőtől értesült „, A magyar jegyző, Miklós, a vajda titkára mondta el nekem, hogy elöbb Rogeronét, ${ }^{59}$ Tricarico grófját kínozták meg, majd öt a földre vetették, ruháitól megfosztva, mintha csak egy igen nagy pallón járkálnának, a gyomrát taposták, s ezután egy égő husánggal a húsát könyörtelenül verték, olyannyira, hogy az egész teste a talpától a feje tetejéig vérzett”. ${ }^{60}$

A zsoldosok egy hónapig kínozták a foglyokat, bár a remélt, 100 ezer aranyforintot megszerezték tölük, továbbra is nyugtalanok voltak, ezúttal már nem törekedtek arra, hogy Lackfival egyezkedjenek, hanem eltervezték, hogy foglyul ejtik és túszként maguknál tartják mindaddig, amíg a király meg nem téríti a fizetségük hiányzó részét. Viszont a németek között akadt egy katona, aki hü volt Lackfihoz, s a lefogására vonatkozó tervet ismertette vele, ezután a vajda magyarjaival titokban az éj leple alatt elvonult Aversától. ${ }^{61}$

56 De restante pecunia ponam penes vos obsidem Nicolaum filium meum vobiscum in Alamaniam deportandum, quousque satisfiat vobis per regiam majestatem. ND 322.

57 Consulo igitur, ut captivos dominos in nostris manibus resumamus et eos ad decentem recactum comprimamus eorum flagello corporeo. ND 323.

58 et ansio quidem animo Theotonici vadunt captivos illos ducere ad torturam Uo.

59 Ruggero Sanseverino, Tricarico, Mileto és Chiaromonte grófja, Roberto unokaöccse, mindketten fogságba estek Melitónál. Pollastri 1991. 52-53.

60 Retulit michi quidam ungarus notarius Nicolaus secretarius domini Voyvadae, quod Rogeronum comitem Tricarici primum torturae dederunt, et eum prosternentes in terram, quasi super trabem maximam ambulantes, nudatis vestibus, ventrem suum calcibus opprimebant, et deinde urentibus viminibus ligneis carnem suam sine misericordia verberabant, et adeo quod totum corpus suum a pianta pedis usque ad verticem sanguinem emanabat. Uo.

${ }^{61}$ „,Akadt pedig abban a seregben egy bizonyos német, kinek nevére nem emlékszem, akit az emlitett úr igen kedvelt és bizalmas viszonyban volt vele, aki a németek ilyenféle tetteiröl puhatolózva, bármit kémlelt ki felölük, azt titkon jelentette neki. S lám egy este, amikor az árulásról tanakodtak, elrendelték a németeknek, hogy a következö napon a zsoldjuk követelésének színe alatt személyesen fogják el a vajdát; amaz, az emlitett úrhoz hü német ezt megtudta, elment hozzá, s jelentette neki a titokban elökészitett ügyet." Erat autem in dicto exercito quidam theotonicus, cujus nominis non recordor, satis dilectus et intimus domino supradicto, qui inquirens de talibus actibus Theotonicorum, quaecumque explorabat ex illis, dicto domino referebat occulte. Et ecce quodam sero, proditoriis tractatibus consequutis, ordinaverunt Theotonici ipsi sequenti die, sub colore petendorum gagiorum, personaliter comprehendere dominum Voyvadam supradictum; quod sentiens theotonicus ille dicti domini fidelis, abiit ab ipsum dominum, nuntians sibi causam parati misterii. ND 325. 
Az utóbbi szövegrészlet nagyobb vonalaiban hasonlít Tarantói Lajos egyik leveléhez, amelyet a szövetségeseinek, a firenzeieknek küldött. A levél 1349. jan. 16-án, az aversai lázadástól nyolc hónappal korábban keletkezett. A tartalma szerint az akkoriban Foggiában lévő zsoldosok elfogták Lackfit és a fiát „Az ellenségeink és az ellenségeitek szokásos magaviselettel vannak Foggiában, s innen nem is mertek volna eltávozni. [...] A választott magyar [Mikcsfi István] kiséretével már eltávozott rossz elöjellel. És hasonlóképpen cselekedett volna a vajda [Lackfi István] is, ha az általa zsoldba hívott németek öt és a fiát akarata ellenére fogva nem tartották volna túszként, hogy megszerezzék azt a kb. 80 ezer aranyforintot, amelyröl azt mondják, hogy a zsoldjuk gyanánt meg kellene kapniuk". ${ }^{62}$ Arról nincs tudomásunk, hogy ennek ténye mennyire volt ismert a Nápolyi Királyságban, illetve Domenico tudott-e róla. A levél tartalmából kiindulva arra lehet következtetni, Foggiánál feltehetően részben ugyanazok a zsoldosok követelték fizetségüket, akik Aversánál tették ugyanezt, tehát az elmaradt zsold kifizetésének egy már kipróbált megoldását tervezték feleleveníteni. Mindazonáltal a levél és a krónika ellentmondanak egymásnak, ha a krónikás tudott volna a foggiai incidensről, azt megemlítette volna az aversai lázadás ismertetésekor. A levélben közölt információk helytállósága is megkérdőjelezhető, minthogy a nápolyi udvar folyamatosan pénz szükében volt, s a háború során jelentősen megfogyatkozott a hadra foghatók száma, ezért Tarantói Lajosnak érdekében állt ellenfeleit kedvezőtlenebb helyzetben feltüntetni, mivel így remélhetett minél előbb támogatást a firenzeiektől.

Matteo Villani firenzei polgárként mások beszámolójára hagyatkozott - s feltehetőleg olyanokéra, akik szintén csak hallomásból értesültek az incidensről -, emiatt némiképpen eltérően ismerteti a zsoldosok és a magyarok tevékenységét. Értelmezése szerint a németek és a magyarok között nem volt különbség, mindkét nép tagjai zaklatták a városlakókat, fosztogattak, s úgy tudta, a foglyoktól összesen 200 ezer aranyforintot szedtek be fogvatartóik. A magyarok Aversában egy nagyobb készletet halmoztak fel és elzártak abból a célból, hogy senki se távozhasson a Királyságból. ${ }^{63}$ Ebböl egyfajta nyomásgyakorlást olvashatunk ki, amivel - Matteo interpretációja alapján úgy vélhetnénk - a magyarok szerették volna maguk mellett tudni a zsoldosokat. Logikailag azonban ez az értelmezés kevésbé helytálló, mivel a zsoldosok fizetség nélküli visszatérése németföldre aligha tünik valószínünek. ${ }^{64} \mathrm{~A}$ készletek elzárása sem tünik észszerünek, mivel félőbb lehetett a magyarok számára, hogy a zsoldosok a számukra elérhető legrövidebb úton szereznek fizetséget, ennek egyik alternatíváját jelentette, hogy új féllel kötöttek szerződést. A magyarok ezen félelme nem volt alaptalan, ugyanis a zsoldosok felajánlották szolgálatukat a nápolyiaknak. ${ }^{65}$ Tanácsosabb úgy értelmeznünk Matteo beszámolóját, hogy ezzel a magyarok és a németek közötti feszültségre próbált utalni.

Domenico és a városlakók világában a zsoldosok a gonosztevők, akik hasonlítanak Polübiosz karthágóiak ellen fellépő zsoldosaihoz: az ismertetett dialógus-sorozatban két helyen is felfedezhető az árulás motívuma. A zsoldosok jellemvonásai megfelelnek A fejedelemben

62 Nostri et vestri inimici sunt more solito Fogie, nec inde ausi fuerunt discedere. [...] Electus Ungarus cum sua familia iam discessit in omine suo malo. Et similiter fecisset Vayvoda, nisi eorum assolidati Theotonici invites eum et eius filium tenuissent obsides pro habendo circha octuaginta millia florenorum auri, quos dicunt se debere recipere de aragagiis eorundem. Dipl. 329.

63 Villani 180-181., 183.

64 Időben hosszadalmas, azért szegődtek el zsoldosnak, mert elszegényedett családból vagy olyan területről szármatnak, amelyet érintett a gazdasági recesszió, s megélhetésüknek az volt az egyetlen biztosítéka, ha fegyveres szolgálatot vállaltak idegen földön. MALLETT 2009. 27.

65 ND 326-327. 
leírtaknak is. Az elemzés során igyekeztem Domenico és a magyarok aspektusából bemutatni a lázadásról szóló szövegrészlet főbb jellemzőit. Viszont érdemes figyelembe venni, a zsoldoskompániák vezéreinek (condottieri) elnevezése onnan ered, hogy a zsoldosok által választott személyek szerződést (conducta, condotta) kötöttek azzal, aki felfogadta őket. ${ }^{66}$ Nem feltétlenül tekinthető árulásnak, amennyiben a szerződésben foglaltak alapján követelték az elmaradt fizetségüket, mert ez jelentette a megélhetésüket. Ha a másik szerződő fél nem tudta teljesíteni az egyezség rá eső részét, jelen esetben az uralkodó nem tudta a meghatározott időre kifizetni az esedékes zsoldot, a zsoldosoknak meg kellett teremteniük annak lehetőségét, hogy valamilyen módon pénzhez jussanak. Ennek egyik formája volt a lakott területek kifosztása, a másik alternatíva pedig a túszejtés és a váltságdíj követelése volt, amely mindössze egy kisebb közösségre vagy néhány emberre rótt terhet. Harmadik megoldásként pedig új szerződést köthettek. ${ }^{67}$

\section{RöVIDÍTÉSEK}

Aokl. = Anjou-kori oklevéltár. XXXIV. Szerk. Teiszler Éva. Budapest-Szeged, 2013.

Chron. = Domenico da Gravina: Chronicon de rebus in Apulia gestis ab a 1333 ad a 1350. A cura di Albano Sorbelli. Città di Castello, 1903-1909.

Cron. sen. = Cronaca senesi. A cura di Alessandro Lisini e Fabio Iacometti. Bologna, 1931-1939.

Dipl. = Magyar diplomácziai emlékek az Anjou-korból. II. Szerk. Wenzel Gusztáv. Budapest, MTA, 1875.

Mach. $=$ Niccolò Machiavelli: A fejedelem . Ford. Lutter Éva. Budapest, Kossuth Kiadó, 2001.

ND = Notar Domenico: Chronicon de rebus in Apulia gestis. A cura di Maria Giovanna Montrone. Matera, Giuseppe Barile Editore, 2008.

Pol. = Polübiosz Történeti könyvei. I. Ford. Forisek Péter - Kató Péter - Muraközy Gyula Patay-Horváth Attila - Sipos Flórián. Máriabesnyő - Gödöllő, Attraktor Kiadó, 2002.

Stor. Pist. $=$ Storie Pistoresi A cura di Silvio Adrasto Barbi. Città di Castello, 1900.

Villani = A három Villani krónikája. Ford. Rácz Miklós. Szerk. Bárány Attila. Máriabesnyő, Attraktor Kiadó, 2011.

\section{FELHASZNÁLT IRODALOM}

Abulafia, David (2005): The South. In John M. NaJemy (ed.): Italy in the Age of the Renaissance 1300-1550. Oxford - New York, Oxford University Press. 208-225.

Baddeley, Welbore St. Claire (1893): Queen Joanna I. of Naples, Sicily and Jerusalem,

66 Waley 1975. 337-371.; Mallett 1999. 217-218.; Contamine 1999. 90-99.; DeVries 2008. 43-56.; Dall'Oro 2008. 66-67.; Mallett 2009. 79-88.

67 A kompániák gazdasági lehetőségeihez lásd: CAFERro 1996.; CAFERro 2009. 
Countess of Provence, Forcalquier and Piedmont. An Essay On Her Times. London, William Heinemann.

Borosy András (2005): Famulusok Magyarországon a 14. században. Aetas 20. évf. 4. sz. 41-77.

Caferro, William (1996): Italy and the Companies of Adventure in the Fourteenth Century. The Historian 58. évf. 4. sz. 795-810.

CAferro, William (2003): 'Slaying the Hydra-Headed Beast': Italy and the Companies of Adventure in the Fourteenth Century. In Donald J. KagaY - L. J. Andrew Villalon (eds.): Crusaders, Condottieri, and Cannon. Medieval Warfare in Societies Around the Mediterranean. Leiden - Boston, Brill. 285-304.

Caferro, William (2009): Travel, Economy, and Identity in Fourteenth-Century Italy: An Alternate Interpretation of the Mercenary System. In Diogo R. CURTO - ERIC R. Dursteller Julius KirShNER - FranCESCA TRIVELlato (eds.): Florence to the Mediterranean and beyond. Essays in honour of Anthony Molho. Firenze, Leo S. Olschki. 363-380.

Caravale, Mario (1991): Domenico da Gravina. In: Dizionario Biografico degli Italiani. http:// www.treccani.it/enciclopedia/domenico-da-gravina_(Dizionario-Biografico)/ (2020. febr. 22.) Casteen, Elizabeth (2015): From She-Wolf to Martyr. The Reign and Disputed Reputation of Johanna I of Naples. Ithaca - New York, Cornell University Press.

Clarke, Paula (2007): The Villani Chronicles. In Sharon Dale - Alison W. Lewin - Duane J. OsheIm (eds.): Chronicling History. Chroniclers and Historians in Medieval and Renaissance Italy. Pennsylvania, Pennsylvania State University Press. 113-143.

Cochrane, Erik W. (1981): Historians and Historiography in the Italian Renaissance. Chicago - London, University of Chicago Press.

Coleman, Edward (2007): Lombard City Annals and the Social and Cultural Hirtory of Northern Italy. In Sharon Dale - Alison W. Lewin - Duane J. Osheim (eds.): Chronicling History. Chroniclers and Historians in Medieval and Renaissance Italy. Pennsylvania, Pennsylvania State University Press. 1-28.

Contamine, Philippe (1999): War in the Middle Ages. Trans. Michael Jones. Oxford - Cambridge, Blackwell.

Csukovits ENIKö (2015): Magyarországról és a magyarokról. Nyugat-Európa magyar-képe a középkorban. Budapest, MTA BTK Történettudományi Intézet.

Csukovits ENIKÖ (2016): Lackfi István Apuliában. In DÁNÉ VeronKA - LuPESCUNÉ MaKÓ MÁRTA - Sipos GÁBOR (szerk.): Testimonio litterarum. Tanulmányok Jakó Zsigmond tiszteletére. Kolozsvár, Erdélyi Múzeum-Egyesület. 61-69.

Dale, Sharon - Alison W. Lewin - Duane J. Osheim (eds.) (2007): Chronicling History. Chroniclers and Historians in Medieval and Renaissance Italy. Pennsylvania, Pennsylvania State University Press.

DALL'Oro, Guido GuERri (2008): Les mercenaires dans les campagnes napolitaines de Louis le Grand, Roi de Hongrie, 1347-1350. In John France (ed.): Mercenaries and Paid Men. The Mercenary Identity in the Middle Ages. Leiden - Boston, Brill. 61-88.

Deliyannis, Deborah Mauskopf (ed.) (2003): Historiography in the Middle Ages. Leiden Boston, Brill.

Delle Donne, Fulvio (1999): Austerità espositiva e rielaborazione creatrice nel ‘Chronicon' di 
Domenico da Gravina. Studi Storici 40. évf. 1. sz. 301-314.

DeVRIES, Kelly (2008): Medieval mercenaries methodology, definitions, and problems. In John France (ed.): Mercenaries and Paid Men. The Mercenary Identity in the Middle Ages. Leiden - Boston, Brill. 43-60.

ENGEL PÁL (1996): Magyarország világi arhontológiája 1301-1457. I. Budapest, História MTA Történettudományi Intézete.

ERwIN, SÉAN (2010): A War of One's Own: Mercenaries and the Theme of Arma Aliena in Machiavelli's Il Principe. British Journal for the History of Philosophy 18. évf. 4. sz. 541-574. FARKas Csaba (2018): Egy udvari katonabáró I. Károly szolgálatában. In NagY Zsolt Dezső - SzAnKa BrigitTA - Szolnoki Zoltán (szerk.): Középkortörténeti tanulmányok 10. A X. Medievisztikai PhD-konferencia (Szeged, 2017. június 7-9.) előadásai. Szeged, Szegedi Középkorász Mühely. 13-34.

Foot, Sarah - Chase F. Robinson (eds.) (2012): The Oxford History of Historical Writing. II. 400-1400. Oxford, Oxford University Press.

KARLINSZKY BALÁZS (2011): Királyi vár - magánvár. A tihanyi vár a 14. században. In RAINER PÁL (szerk.): A Veszprém megyei múzeumok közleményei. Veszprém. 25-36.

Kelly, Samantha (2003): The New Solomon. Robert of Naples (1309-1343) and FourteenthCentury Kingship. Leiden - Boston, Brill.

Kelly, Samantha (2011): The Cronaca di Partenope. An Introduction to and Critical Edition of the First Vernacular History of Naples (c. 1350). Leiden - Boston, Brill.

Kiesewetter, Andreas (2006): Luigi d'Angiò, re di Sicilia. In: Dizionario Biografico degli Italiani. http://www.treccani.it/enciclopedia/luigi-d-angio-re-di-sicilia_(Dizionario-Biografico)/ (2020. febr. 22.)

LÉOnARD, Émile G. (1932): Histoire de Jeanne 1re, reine de Naples, comtesse de Provence (1343-1382). I. Monaco - Paris.

LÉONARD, Émile G. (1967): Gli Angioini di Napoli. Traduzione dal francese di Renato Liguori. Milano.

Loud, Graham A. (2007): History Writing in the Twelth-Century Kingdom of Sicily. In SHAron Dale - Alison W. Lewin - Duane J. Osheim (eds.): Chronicling History. Chroniclers and Historians in Medieval and Renaissance Italy. Pennsylvania, Pennsylvania State University Press. 29-54.

Mallett, Michael (1999): Mercenaries. In Maurice Keen (ed.): Medieval Warfare. A History. Oxford - New York, Oxford University Press. 209-229.

Mallett, Michael (2009): Mercenaries and their Masters. Warfare in Renaissance Italy. Barnsley, Pen and Sword Military.

Miskolczy IstváN (1933a): Nagy Lajos nápolyi hadjáratai. (Első hadjárat). Hadtörténelmi Közlemények 34. 46-70.

Miskolczy IstváN (1933b): Nagy Lajos nápolyi hadjáratai. Hadi események a két hadjárat között. Hadtörténelmi Közlemények 34. 123-146.

Miskolczy István (1934): Nagy Lajos második nápolyi hadjárata (1350). Hadtörténelmi Közlemények 35. 41-57.

Morelli, SERENa (2000): La storiografia sul Regno angioino di Napoli. Una nuova stagione di studi. Studi Storici 41. évf. 4. sz. 1023-1045. 
Musto, Ronald G. (2018): Writing Southern Italy Before the Renaissance. Trecento Historians of the Mezzogiorno. Abingdon - New York, Routledge.

NusSDorfer, Laurie (2009): Brokers of Public Trust. Notaries in Early Modern Rome. Baltimore, Johns Hopkins University Press.

Pollastri, Sylvie (1991): Une famille de l'aristocratie napolitaine sous les souverains angevins: les Sanseverino (1270-1420). Mélanges de l'École française de Rome. Moyen-Age 103. évf. 1. sz. 237-260.

PóR Antal (1892): Nagy Lajos 1326-1382. Budapest, Franklin Társulat.

TEISZLER ÉVA (2015): I. Lajos király nápolyi trónigénye a diplomácia tükrében. Acta Universitatis Szegediensis: acta historica 138. 63-79.

Vaglienti, Francesca Maria (1999): Werner von Urslingen. In Lexikon des Mittelalters. IX. Stuttgart - Weimar, Metzler. 4-5.

Van Caenegem, Raoul Charles (1979): Guide to the Sources of Medieval History. With the collaboration of F. L. Ganshof. Amsterdam - New York - Oxford, North-Holland Publishing Company.

Vasina, Augusto (2003): Medieval Urban Historiography in Western Europe (1100-1500). In Deborah Mauskopf Deliyannis (ed.): Historiography in the Middle Ages. Leiden - Boston, Brill. 317-352.

Violante, Francesco (2016): Dominicus de Gravina. In Graeme DunPhy - Cristian Bratu (eds.): Encyclopedia of the Medieval Chronicle. Brill Online: http://dx.doi.org/10.1163/22132139_emc_SIM_00891 Hozzáférés: 2020.02.22. 18:24.

Waley, Daniel P. (1975): Condotte and Condottieri in the Thirteenth Century. Proceedings of the British Academy 61. 337-371.

WERTNER Mór (1908): Újabb nemzetségi kutatások. Turul 26. 122-157.

ZABBIA, MARINO (1999): I notai e la cronachistica cittadina italiana nel Trecento. Roma, Istituto Storico per il Medioevo. 